TELEIOS: Jurnal Teologi dan Pendidikan Agama Kristen

Sekolah Tinggi Teologi Transformasi Indonesia

Volume 1, Nomor 1, Juni 2021 (hal. 30-44)

http://stttransformasi-indonesia.ac.id/e-journal/index.php/teleios/index

\title{
Kematian Kristus dan Implementasinya Dalam Kehidupan Kristen Masa Kini
}

\section{Steven Tommy Dalekes Umboh}

Sekolah Tinggi Teologi Missio Dei Manado

stevenumboh82@gmail.com

\begin{abstract}
Abstrak
Sejarah telah mencatat bahwa kematian Kristus selalu menjadi perdebatan khususnya bagi mereka yang meragukan otenistas benarkah Kristus meninggal secara faktual? Walau ada yang meragukan kematian Kristus, namun Alkitab tetap menjadi patokan utama yang harus dipercayai, bahwa kematian-Nya merupakan memiliki bukti keotentikan sejarah maupun secara doktrinal. Bukti kematian Kristus bersifat absolut dengan adanya tanda-tanda yang dikemukakan oleh para penulis Alkitab yang menjadi saksi mata dari peristiwa tersebut. Metode yang digunakan pada tulisan ini adalah metode kualitatif deskriftif dengan pendekatan kepustakaan. Hasil pada uraian artikel mengemukakan kematian Kristus terbingkai secara sistemtis dalam narasi Kitab Suci. Selain itu bukti secara arkeologis dan medis menyatakan hal itu. Implementasi bagi orang percaya dari kematian Kristus agar semakin menunjukkan kehidupan yang berubah melalui buah-buah roh, serta tidak melupakan perintah Allah dalam merealisasikan perintah Amanat Agung.
\end{abstract}

Kata Kunci: Kematian Kristus, Kitab Suci, Orang Kristen.

\begin{abstract}
History has recorded that christ's death has always been a debate especially for those who doubt whether Christ died factually? Although some doubt christ's death, the Bible remains the main benchmark to be believed, that His death Was evidence of historical authenticity as well as doctrinally. The evidence of Christ's death is absolute with the signs presented by the Bible writers who bear eyewitnesses to the event. The method used in this paper is a descriptive qualitative method with a library approach. The results in the article description suggest christ's death is framed systemically in the Scriptural narrative. In addition archaeological and medical evidence states it. Implementation for believers from christ's death to further demonstrate a life that changes through the fruits of the spirit, and not forgetting god's command in realizing the command of the Great Commission.
\end{abstract}

Keywords: The Death of Christ, Scripture, Christians. 


\section{Pendahuluan}

Pada abad yang lampau dengan penemuan hukum Relativitas $\mathrm{E}=\mathrm{Mc}^{2}$ oleh Albert Einstein maka konsep relativitas bukan hanya secara khusus dinyatakan dalam bidang fisika tetapi istilah relativitas sudah dipakai secara umum dalam konteks sosial masyarakat. Relativitas sudah menjadi istilah umum yang mengyatakan bahwa segala sesuatu bersifat relatif. Dengan adanya hal ini, konsep (relativitas) ini menjadi salah-satu pegangan untuk menolak hal-hal yang bersifat supanaturaldan teologis yang diungkapkan dalam Alkitab. ${ }^{1}$

Dalam investigasi sejarah teologi Kristen ternyata penolakan untuk hal-hal yang diungkapkan oleh Alkitab yang bersifat teologis, dan super nature, ternyata sudah terjadi jauh sebelum Einstein menemukan hukum Relativitasnya. Bahkan hal ini nampak dalam kita membaca Alkitab, dan sejarah teologi Kristen. Penolakan terhadap hal-hal yang bersifat teologis dan supernatural dalam Alkitab adalah implikasi dari filsafat! ${ }^{2}$ Dimana bukan lagi Teosentris dan Kristosentris sebagai sentral atau tolok ukur dari setiap pemahaman atau konsep teologi tetapi ialah Antroposentris. Logika manusia yang ditempatkan tertinggi sebagai instansi untuk mengkaji segala sesuatu. Sebagaimana dinyatakan oleh filsuf aliran Rasionalisme, yakni Baruch de Spinoza yang menjadikan logika manusia sebagai homo mensura: "Memegang Alkitab sebagai firman Allah berarti mengubah kepercayaan menjadi takhayul." Spinoza juga menulis "Saya takut bahwa orang yang membantah adalah terlalu takut, dan dengan demikian tidak mampu percaya", maka dia dalam bahaya "mengubah agama menjadi takhayul, dan menyembah kertas serta tinta sebagai ganti Allah."3 Mengenai realitas ini, Linnemann menyatakan bahwa "Segala ilmu dan juga teologi historis-kritis didasarkan oleh penolakan terhadap wahyu Allah, dan oleh pikiran-pikiran yang menyembah akal manusia dan ilmu pengetahuan sebagai ilah. Akal budi dan ilmu pengetahuan menjadi berhala bagi manusia modern. ${ }^{4}$

Alkitab menyatakan bahwa Kristus mati bagi dosa-dosa kita. Kebenaran yang sangat indah dipaparkan Yesus kepada guru Israel yakni Nikodemus "Karena begitu besar kasih Allah akan dunia ini sehingga Ia mengaruniakan Anak-Nya yang tunggal, agar setiap orang

\footnotetext{
${ }^{1}$ Abdul Karim, "Sejarah Perkembangan Ilmu Pengetahuan," Fikrah 2, no. 2 (2014).

${ }^{2}$ Bobby Kurnia Putrawan, Edi Sugianto, and Yan Kristianus Kadang, "Refleksi Pada Relasi Antara Teologi Dan Filsafat Dalam Perspektif Teologi Injili," Evangelikal: Jurnal Teologi Injili dan Pembinaan Warga Jemaat 4, no. 2 (2020): 223-234.

${ }^{3}$ Eta Linnemann, Teologi Kontemporer: Ilmu Atau Praduga? (Istitut Injil Indonesia, 1991), 33.

${ }^{4}$ Linnemann, Teologi Kontemporer: Ilmu Atau Praduga?
} 
yang percaya kepada-Nya tidak akan binasa melainkan beroleh hidup yang kekal" (Yoh. 3:16). Demikian juga pernyataan Kristus dalam Injil Markus "Anak manusia datang bukan untuk dilayani, melainkan melayani dan memberikan diri-Nya sebagai tebusan bagi banyak orang" (Mar. 10:45). Dan ada begitu banyak bukti Alkitab yang menyatakan perihal kematian Kristus. Dengan kemajuan pengetahuan zaman sekarang, dengan berkembangnya konsep-konsep yang keliru mengenai Kristus, kebenaran yang kita yakini bahwa Yesus mati bagi dosa-dosa kita, dinyatakan sebagai konsep yang keliru. Sebagai orang percaya setiap paham yang menyangkali akan kebenaran Alkitab haruslah dikaji dalam terang Alkitab sebagai firman Allah. Pegajaran historis-teologis bahwa Kristus mati adalah sumber penghiburan bagi orang percaya dalam menjalani kehidupan yang penuh dengan pegumulan.

Pada waktu Kristus mati, sejarah menyatakan bahwa ada individu-individu yang menolak kebenaran ini. Kematian Kristus diungkapkan sebagai kebohongan bahkan yang lebih ekstrim Kristus dikatakan hanya sebagai pribadi dalam mitos orang Kristen!! Hal ini nyata dalam pernyataan filosofis filsuf Amerika, Thomas Paine: "Tidak ada sejarah yang dicatat pada saat Yesus Kristus dikatakan pernah hidup yang berbicara tentang keberadaan orang yan semacam itu, bahan laki-laki yang semacam itu". 5 Dalam essainya yang terkenal Why Iam Not a Christian, Bertrand Russel menulis: "Secara historis sangat diragukan apakah Kristus pernah hidup, dan jika Ia hidup kita tidak tahu apa-apa tentang Dia."6 Dari pernyataan-pernyataan ini sangat jelas bahwa pribadi Kristus, kehidupan, pelayanan serta kematian-Nya tidak diterima sebagai kebenaran historis yang objektif, melainkan ditanggapi sebagai kebenaran yang subjektif belaka!! Pertumbuhan jemaat adalah harapan terbesar bagi seorang pelayan Tuhan. Ia mengharapkan pelayanan yang ia hadapi dapat berkembang dengan baik sehingga banyak jiwa yang diselamatkan.

Pengajaran yang benar menghasilkan jemaat yang berkualitas, yang bertumbuh sesuai dengan keinginan Allah bagi gereja-Nya dalam dunia. Pengajaran firman yang bersifat doktrinal sangat bermanfaat bagi pertumbuhan iman Kristen setiap jemaat Tuhan. Purwoto menyebut gereja adalah produk baru dalam Tuhan Yesus yang maknanya melampaui umat Perjanjian Lama. Gereja yang adalah produk baru yang didirikan oleh Kristus memiliki tanda-tanda gereja sejati. ${ }^{7}$ Karena itu setiap konsep-konsep yang keliru harus diuji secara

\footnotetext{
${ }^{5}$ Norman L Geisler, Ketika Alkitab Dipertanyakan (ANDI, 2006), 115.

${ }^{6}$ Bertrand Russell and James J Ravell, Why I Am Not a Christian (Haldeman-Julius Publications, 1929).

${ }^{7}$ Paulus Purwoto, "Tinjauan Teologis Tentang Gereja Sejati Dan Aplikasinya Bagi Pelayanan Gereja Kontemporer," SHAMAYIM: Jurnal Teologi dan Pendidikan Kristiani 1, no. 1 (2020): 45-57.
} 
objektif dan komprehensif dari sudut pandang Kitab Suci. Tulisan ini akan membahas bagaimana kematian Kristus dalam kaitan dengan kehidupan Kristen di Masa kini? Dengan membahas topik ini ada manfaat secara praktis dan teoritisnya. Manfaat secara teoritisnya, kajian ini menjadi sumbangsih dalam pembelajara, sementara praksisnya menjadi refleksi bagi orang percaya untuk terus bertumbuh dalam persekutuan dengan Allah.

\section{Metode Penelitian}

Abdurahman mengemukakan bahwa penelitian itu sebagai upaya atau kegiatan yang bertujuan untuk mencari jawaban yang sebenar-benarnya terhadap suatu kenyataan atau realita yang dipikirkan atau dipermasalahkan untuk memperoleh pengetahuan ilmiah tertentu yang berguna, baik bagi aspek keilmuan maupun bagi aspek kepraktisannya. ${ }^{8}$ Metode yang digunakan dalam penulisan artikel ini adalah metode studi deskriftif. Pada umumnya metode ini dipergunakan untuk penyelidikan kebenaran yang bersifat relatif, teoretis dan menggunakan hermenetika sebagai langkah untuk mencari makna dan interpretasi. ${ }^{9}$ Prosedural dalam penulisan ini dimulai dari mengumpulkan dan membaca berbagai referensi abik dari jurnal maupun buku. Kemudian penulis mendeskrifsikan dan memaparkan secara konferenshif untuk ditarik kesimpulan.

\section{Hasil dan Pembahasan}

\section{Tentang Yesus Kristus}

Yesus Kristus adalah sebuah nama dan gelar. Yesus Kristus adalah Allah yang berinkarnasi menjadi manusia. Kebenaran Kristus yang adalah Allah dinyatakan oleh Kitab Suci. Nama Yesus bukanlah gelar saja bagi penyandang nama itu. Arti nama itu bentuk Yunaninya ialah vihsou/j yang artinya adalah "Yahweh adalah Juruselamat." Para penulis PB benar-benar menyadari arti ini (Mat. 1:21). Jadi nama itu menunjukkan tugas yang dibebankan kepada Yesus, dan pengertian ini kemudian terungkap dalam gelar juruselamat, yang mulanya hanya merupakan keterangan tentang tugas Yesus. Yesus adalah nama pribadi Juruselamat. ${ }^{10}$ Berdasarkan penjelasan istilah Yesus Kristus, maka Yesus Kristus

\footnotetext{
${ }^{8}$ Ating Somantri Maman Abdurahman, Sambas Ali Muhidin, Dasar-Dasar Metode Statistika Untuk Penelitian (Bandung: CV Pustaka Setia, 2011), 13.

${ }^{9}$ Sonny Eli Zaluchu, "Metode Penelitian Di Dalam Manuskrip Jurnal Ilmiah Keagamaan," Jurnal Teologi Berita Hidup 3, no. 2 (2021): 249-266.

${ }^{10} \mathrm{~J}$ D Douglas and others, "Ensiklopedi Alkitab Masa Kini Jilid I," Jakarta: Yayasan Komunikasi Bina Kasih/OMF (2003): 589.
} 
adalah nama pribadi yang berarti "Allah yang menyelamatkan" dan Mesias adalah "yang diurapi.” Jadi Yesus Kristus adalah sebuah nama dan gelar yang melekat kepada Kristus, yang mengeksplanasikan bahwa Yesus kristus adalah Allah yang berinkarnasi menjadi manusia untuk menyelamatkan manusia dengan melaksanakan misi yang diperintahkan oleh Allah karena itu Yesus diurapi sebagai hamba Tuhan. ${ }^{11}$

Untuk memahami Kristus secara sistimatis dalam konseps teologis secara mendalam, maka kesejarahan Kristus sangat penting, karena hal ini merupakan sebuah sumber yang kongkrit dan faktual, sekaligus juga akan menjadi sebuah latar belakang yang mengarahkan pada ajaran yang benar dan penting mengenai Yesus Kristus. Dalam hubungan dengan maksud tersebut di atas, maka informasi tentang Kristus haruslah diinformasikan secara komprehensif menurut data Alkitab. Oleh karena itu hal yang sangat penting yang harus disampaikan adalah mengenai eksistensi Kristus dari kekekalan masa lampau; Sejarah dan tipologi Kristus dalam Perjanjian Lama; Nubuatan Inkarnasi dalam Perjanjian Lama; Inkarnasi Kristus dalam Perjanjian Baru; dan Kehidupan Kristus. Persoalan yang masih dipersoalkan sampai sekarang ini adalah tentang keberadaan Kristus sebagai Allah, pribadi kedua dari Trinitas yang berada dalam masa kekekalan. Masalah kekekalan Kristus sangat ditentang oleh orang Yahudi (Yoh. 8:12), dan begitu banyak orang sampai masa kini, menolak ke-Allahan Kristus, seperti Saksi Yehovah. Orang Yahudi menolak kekekalan Kristus. Bayak individu berasumsi bahwa Yesus sudah ada sebelum dunia dijadikan, tapi sifatnya adalah roh yang diciptakan!

John F. Walvoord menyatakan bahwa: "Sekalipun orang Yahudi dan banyak orang tidak mengakui kekekalan Kristus, tetapi Alkitab dengan jelas dan tegas mengatakan bahwa Yesus adalah kekal adanya karena Dia adalah Allah." ${ }^{12}$ Yesus sendiri dengan jelas memberitahukan bahwa Ia berasal di Sorga yang diutus oleh Allah dan Ia juga berbicara tentang kemuliaan-Nya sebelum inkarnasi di dunia (Mik. 5:1; Yoh. 17:5). Di sisi lain ditegaskan bahwa kalau Yesus bukan berasal dari kekekalan, maka eksistensi-Nya akan dipengaruhi oleh lingkungan-Nya, situasi dan dengan pihak-pihak yang lain. Perjanjian Baru juga memberitahukan bahwa Yesus adalah kekal karena Dia adalah Allah, dan hal tersebut paling banyak diekspos oleh Injil Yohanes dan kitab yang lain seperti Kitab (Kol. 1:16-17). ${ }^{13}$

\footnotetext{
${ }^{11}$ John F Walvoord, "Yesus Kristus Tuhan Kita,” Surabaya: Yakin (1969): 18

${ }^{12}$ John F. Walvoord., Yesus Kristus Tuhan Kita. (Surabaya: YAKIN, t.t), 18

${ }^{13}$ Walvoord, "Yesus Kristus Tuhan Kita."
} 
Bukti lain juga tentang kekekalan kristus terdapat dalam pernyataan-pernyataan mengenai janji-janjiNya yang kekal, dengan jelas disampaikan oleh Paulus bahwa Allah telah memilih manusia supaya kudus dan tak bercacat di hadapan Kristus sebelum dunia dijadikan. Yesus sendiri pun menyatakan bahwa Dia adalah Alfa dan Omega, yang awal dan yang akhir. Pernyataan ini menunjukkan bahwa Kristus telah berada dari masa yang tidak ada awal dan yang akhir, dengan kata lain bahwa Yesus sudah ada dari kekekalan ke kekekalan. Mengenai kekekalan Kristus, Charles C. Ryrie menyatakan bahwa: "Kekekalan tak hanya berarti bahwa Kristus sudah ada sebelum kelahiran-Nya atau bahkan sebelum penciptaan, tetapi bahwa Ia selalu ada, selama-lamanya." 14

Jika kekekalan Kristus tidak diakui, maka berbicara tentang Allah Trinitas hanyalah sebuah mitos saja, Kristus bukan Allah yang sesungguhnya, dan Allah adalah pembohon besar! Oleh karena itu yang benar adalah Kristus sudah ada dari kekekalan ke kekekalan. Hal ini terlihat pada relasi Allah yang sehakekat dengan keTritunggalan Allah, yaitu Allah Bapa, Allah Anak, Allah dan Roh Kudus. Dalam Ibrani 1:3a dikatakan bahwa "Kristus adalah cahaya kemuliaan Allah dan gambar wujud Allah dan menopang segala yang ada dengan fiman-Nya yang penuh kekuasaan." Perhatikan kata gambar dalam bahasa Yunani berarti karakter yang menunjukkan bahwa Kristus adalah wujud atau inti sifat Allah yang persis sama. Para nabi juga mengakui kekalan Kristus yang disebut Mesias yang akan dating kedunia (Mik. 5:1; Yes. 9:5). Pentingnya kekekalan Kristus adalah untuk membuktikan bahwa jikalau Kristus tidak kekal, maka tidak ada Tritunggal, Kristus bukan sepenuhnya Allah, dan berbohong.

Ketika berbicara tentang Kristus dalam kekekalan, maka hal yang tidak dapat dipisahkan adalah berbicara mengenai Pra-eksistensi atau masa sebelum kelahiran Kristus. Dengan kata lain bahwa Yesus sudah ada sebelum penciptaan dan adanya waktu. Praeksistensi Kristus memliki makna yang sangat penting bagi kehidupan manusia, terlebih dalam hubungan dengan leberadaan Kristus sebagai Allah. Adapun pentingnya praeksistensi Kristus, yaitu untuk meyakinkan dan membuktikan bahwa Dia benar sudah ada sebelum segaa sesuatu dibuat. Kalau Kristus tidak ada pada kekekalan, maka Kristus bukanlah Allah dan Kristus juga dapat disebut pembohong adanya. Untuk membuktikan bahwa Kristus adalah Allah, maka pembuktiannya, Kristus harus berasal dari Sorga, karya dan pekerjaan-

\footnotetext{
${ }^{14}$ Charles C Ryrie and Teologi Dasar, “Cet 3,” Yogyakarta: Yayasan Andi (1986): 535.
} 
Nya adalah menciptakan. Jadi kalau Kristus bukan berasal dari Sorga dan bukan Pencipta, maka Kristus bukanlah Allah. Tapi Alkitab memberikan informasi yang sangat luar biasa bagi kita bahwa Kritus adalah Allah yang menciptakan dunia dan segala isinya (Yoh. 1:3).

\section{Kematian Kristus dalam Perspektif Alkitab}

Kematian Kristus adalah tindakan Allah yang jelas dan nyata. Kematian Kristus adalah bukti kasih Allah kepada manusia. Kematina Kristus kematian Kristus merupakan peristiwa yang sangat penting bagi kehidupan manusia sekaligus juga sebagia pembuktian terhadap penyataan Allah dan penyataan Allah kepada manusia. ${ }^{15}$ Sebab jika Kristus tidak mati di atas kayu salib, maka kekristenan hanya merupakan rekaan manusia; kekristenan hanya merupakan pengakuan dari kelompok orang yang stress; kekristenan hanyalah suatu keyakinan yang tidak ada makna dan tujuan yang jelas dan benar. Kekristenan hanya deklarasi dari kelompok orang yang ingin menonjolkan diri ataupun haus kekuasaan. Yang benar adalah Kristus benar-benar mati di bukit Golgota. ${ }^{16}$

\section{Bukti Medis Terhadap Penderitaan Sampai Kematian Kristus}

Untuk membuktikan kekeliruan pernyataan-pernyataan yang meragukan kematian Kristus, maka pada bagian ini akan diuraikan secara medis (ilmiah) bahwa Kristus benarbenar mati di kayu salib, bukan pingsan sebagaimana argumentasi dari Barbara Thiering, seorang akademik dari Australia yang menimbulkan kegemparan tahun 1992 dengan menghidupkan kembali teori pingsan dalam bukunya Jesus and the Riddle of the Dead Sea Scroolls ${ }^{17}$.

Kapankah penderitaan Yesus dimulai? Alexander Metherell, menyatakan bahwa penderitaan Kristus dimulai di Getsemani. “. . . Di sana. . . Ia berdoa semalam-malan. Selama proses itu Ia mengantisipasi datangnya peristiwa-peristiwa pada hari berikutnya. Karena Ia mengetahui beratnya penderitaan yang akan Ia pikul, Ia sungguh-sungguh wajar mengalami tekanan psikologis yang sangat besar." 18

Alkitab menyatakan bahwa Yesus sudah tahu peristiwa yang akan terjadi (menanti-Nya). Mark A. Marinella mengungkapkan bahwa: "Bahkan ketika menjelang malam, Yesus

\footnotetext{
${ }^{15}$ Henry C. Thiessen, Teologi Sistematika, Cetakan Ke. (Malang: Penerbit Gandum Mas Malang, 2010).

${ }^{16}$ Paul Enns, The Moody Hanbook Of Theology (Malang: SAAT, 2010).

${ }^{17}$ Thiering Barbara, "Jesus and the Riddle of the Dead Sea Scrolls," San Francisco (1992).

${ }^{18}$ Mark A Marinella, Yesus Yang Disalib Bagiku (Yogyakarta: ANDI, 2009), 251.
} 
kemungkinan mulai mengalami stress. Lama sebelum penyaliban, Kristus tahu bahwa Dia akan disalibkan (Yoh. 12:27, 32)." ${ }^{19}$ Lebih lanjut Marinella mengkonsepsikan bahwa: "Karena telah mengetahui apa yang akan segera terjadi, disertai ketegangan saat makan bersama pengkhianat-Nya, dapat menyebabkan Yesus tidak nafsu makan. Mengetahui lebih dulu bisa mengakibatkan respon fisik di luar kemauan seperti tachycardia (detak jantung yang cepat), nausea (muntah), pusing, gemetar, diaphoresis (berkeringat), dan mungkin sakit kepala." Ketika seseorang menghadapi menghadapi situasi yang sangat sulit, satu bagian otak tertentu akan mengeluarkan zat kimia yang disebut neurotransmitter, dan kelenjar adrenalin akan mengeluarkan hormone seperti cortisol, ephineprine, dan norephineprine. Hormon dan zat kimia itu akan menekan jantung dan menyebkan tachycardia; mendorong kelenjar keringat mengeluarkan keringat; pembulu darah akan mengalir deras dan menyebabkan pusing, dan perubahan sistem saraf menimbulkan sakit kepala dan gemetar."20

Jika kita bisa mengukur tingkat hormone stress, cortisol, norepinephrine dan epinephrine dalam darah Yesus saat Perjamuan Terakhir, hormon tersebut pastilah sangat tinggi- untuk mengantisipasi hal-hal mengerikan yang akan datang. Analisis Metherell di Getsemani Yesus mengalami tekanan psikologis yang sangat besar, sebagaimana konsepsi injil bahwa Kristus meneteskan keringat darah. Keringat darah yang menetes ini adalah suatu kondisi medis yang dikenal dengan nama hematidrosis (diasosiasikan tekanan psikologis tingkat tinggi). ${ }^{21}$ Hematidrosis terjadi karena "Kegelisahan yang hebat menyebabkan terlepasnya zat-zat kimia yang memecahkan kapiler-kapiler dalam kelenjarkelenjar keringat. Akibatnya terjadi sedikit pendarahan dalam kelenjar-kelenjar ini, dan keringat yang keluar disertai dengan darah (hanya sedikit darah)." ${ }^{22}$ Akibat hematidrosis ialah kulit menjadi amat sangat rapuh sehingga ketika Yesus dicambuk oleh serdadu Roma keesokan harinya, kulitnya akan menjadi sangat, sangat sensitiv.

Alkitab mengkonsepsikan kepada kita bahwa Yesus disesah (dicambuk). Sejarah membuktikan bahwa pencambukkan yang dilakukan oleh serdadu-serdadu Roma adalah sangat brutal dan sadis. Mereka mencambuk terhukum sebanyak tiga pulu sembilan kali

\footnotetext{
${ }^{19}$ Marinella, Yesus Yang Disalib Bagiku.

${ }^{20}$ Ibid.

${ }^{21}$ Ibid.

${ }^{22}$ Ibid.
} 
cambukan, tetapi seringkali lebih dari jumlah yang ditetapkan, tergantung suasana hati si serdadu yang melaksanakan pukulan. ${ }^{23}$ Bentuk dan jenis cambukannya dari cemeti dari kepangan tali kulit dengan bola-bola logam yang dijalin ke dalamnya. Ketika cemeti itu menghantam daging, bola-bola ini akan menyebabkan memar atau lebam yang dalam, yang akan pecah terbuka akibat pukulan selanjutnya. Dan cemeti itu juga memiliki potonganpotongan duri tajam, yang akan mengiris daging dengan hebat. Metherell menyatakan bahwa "Punggung yang dipukul itu akan menjadi begitu tercabik-cabik sehingga sebagian dari tulang belakang kadangkala terlihat akibat irisan yang dalam, sangat dalam. Pencemetian itu akan ditimpakan ke segala arah dari bahu turun ke punggung, pantat, dan kebelakang kaki. Itu sangat mengerikan." ${ }^{24}$ Seorang dokter yang telah mempelajari pemukulan Roma mengatakan bahwa: "Selagi pencambukan berlanjut, luka koyakan akan tercabik sampai ke otot-otot kerangka di bawahnya dan menghasilkan goresan-goresan daging berdarah yang gemetar."

\section{Penderitaan Yesus di Salib}

Kematian saat ini bagi kriminal hukuman mati berlangsung cepat, tetapi kematian melalui salib adalah kematian yang perlahan-lahan dan sangat menderita serta sangat terhina karena menjadi tontonan banyak orang. Ketika Yesus sampai di tempat penyaliban, "Ia akan dibaringkan, dan kedua tangan-Nya akan dipakukan dalam posisi terentang ke batang kayu horizontal. Balok salib ini disebut patibulum, dan pada tahap ini balok tersebut dipisahkan dari batang kayu vertikal, yang secara permanen ditancapkan di tanah."25

Peninggalan arkeologis tentang orang yang disalibkan, yang ditemukan di dekat Yerusalem, menunjukkan bahwa pakunya berbentuk persegi dan meruncing. Ukurannya kurang lebih 12 sampai $17 \mathrm{~cm}$, dan agak mirip dengan paku rel kereta api. ${ }^{26}$ Paku besi itu menembus deretan tulang pergelangan yang disebut tulang carpal. Di bagian tengah tulang carpal, di bagian yang dikenal dengan nama carpal tunnel, terdapat saraf median sensorikmotorik yang besar. ${ }^{27}$ Saraf median memberikan fungsi motorik pada beberapa otot tangan

23 Sonny Zaluchu, "Penderitaan Kristus Sebagai Wujud Solidaritas Allah Kepada Manusia," DUNAMIS: Jurnal Penelitian Teologi dan Pendidikan Kristiani (2017).

${ }^{24}$ Marinella, Yesus Yang Disalib Bagiku.

${ }^{25}$ Supriadi Oet, “Teladan Penderitaan Tuhan Yesus Berdasarkan Matius 27: 32-44,” Manna Rafflesia (2020).

${ }^{26}$ Marinella, Yesus Yang Disalib Bagiku.

27 Ibid. 
dan rasa pada sebagian besar tangan. Jika ditempaytkan di bagian sisi telapak pergelangan tangan, paku itu akan menembus atau menusuk saraf median dan menimbulkan rasa sakit yang hebat, seperti terbakar dan tertusuk. Sejenis ketidaknyamanan yang dikenal dengan istilah rasa sakit neuropathic. Kelumpuhan otot tangan juga bisa terjadi. Gerakan tangan dan pergelangan tangan berikutnya akan menimbulkan rasa sakit yang luar biasa (excruciating).

\section{Deretan Peristiwa Penyaliban Yesus}

Dalam penyaliban Yesus menuju Kalvari, Kristus memanggul salib sehinga Ia tak kuat dan tak mampu memkulnya lagi dan Simon orang Kirene dipaksa untu memikulnya. Adapun deretan dari penyaliban Kristus pertama setibanya di Kalvari, Kristus disuguhkan anggur bercampur dengan empedu untuk menumpulkan syaraf-syaraf-Nya (Mat. 27:33,34). Kedua, Seruan pertama di salib: "Bapa, ampunilah mereka, karena mereka tidak mengetahui apa yang mereka perbuat." (Luk. 23:34). Ketiga, para serdadu-serdadu membagi-bagikan pakaian-Nya dan membuat undi untuk memperoleh jubah-Nya (Mat. 27:35). Keempat, sindiran-sindiran imam besar, ahli-ahli Taurat dan orang banyak terhadap Kristus (Mrk. 15:29-32). Kelima, Salah-satu penyamun percaya kepada-Nya (Luk. 23:39-43) seruan kedua disalib: "Hari ini engkau bersama-sama dengan Aku di dalam Firdaus." Keenam, Seruan ketiga: "Ibu, inilah anakmu” dan kepada Yohanes "Inilah ibumu” (Yoh. 19:26-27). Ketujuh, uasana kegelapan selama 3 jam (Mat. 27:45). Kedelapan, seruan "Bapa ke dalam tangan-Mu, Ku serahkan nyawa-Ku” (Luk. 23:46). Deretan peristiwa penyaliban Yesus menunjukkan betapa istimewa kemaian-Nya dialam raya ini, karena didasari pada aspek teologinya yang penting dan dampak kematian bagi kepentingan manusia. ${ }^{28}$

\section{Makna Kematian Kristus}

Berbicara mengenai makna teolgis tentang kematian Kristus, Marantika mengkonsepsikan bahwa: "Kematian Kristus bukanlah kematian sia-sia, karena ketidakberdayaan melawan keputusan hukuman salib. Namun sebaliknya, justru dalam kematian-Nya mengandung banyak makna, dan pekerjaan Allah." ${ }^{29}$ Adapun makna kematian Kristus, yaitu: "Untuk menggenapi rencana Allah yang harus diterima, sebab Kristus mati bagi manusia." Kristus tidak perlu mati seandainya bukan karena dosa-dosa

${ }^{28}$ Yohanes Adrie Hartopo, “Kematian Yesus Kristus Menurut Lukas 23: 44-48,” Jurnal Amanat Agung 13, no. 2 (2017): 207-241.

${ }^{29}$ Chris Marantika, Kristologi (Jakarta: Iman Press, 2005). 
manusia. Ia sendiri tidak berdosa (2 Kor. 5:21). Jalan Keselamatan ini adalah pekerjaan Allah sendiri. Ini bukan pekerjaan manusia. Kristuslah satu-satunya yang telah menempuh jalan kematian yang membawa hidup itu secara sempurna. Itulah sebabnya hanya Dia yang menjadi satu-satunya jalan keselamatan (Yoh. 14:6). Rencana dan usaha Allah yang telah disempurnakan dan dilaksanakan oleh Kristus itu harus diterima jika ingin mendapatkan hidup yang kekal. Kematian Kristus tidak secara otomatis merubah status dan kondisi manusia. Kristus tidak dapat menyelamatkan manusia, jika manusia terpisah dari tanggung jawab dan tanggapan manusia terhadap-Nya.

Thiessen menyatakan tentang makna kematian Kristus secara teologis merupakan tujuan utama penjelmaan-Nya, karena kematian Kristus bukanlah suatu kecelakaan atau suatu pikiran yang timbul kemudian, tetapi merupakan pelaksanaan suatu tujuan tertentu yang berhubungan dengan penjelmaan. Penjelmaan bukanlah merupakan tujuan, penjelmaan merupakan suatu sarana untuk mencapai tujuan tertentu, dan tujuan tersebut ialah penebusan orang yang hilang lewat kematian Kristus di kayu salib. Kematian Kristus merupakan pokok tema Injil. Istilah Injil berarti kabar baik seiring dengan itu istilah ini dipakai dalam berbagai cara. Kematian Kristus sangat penting bagi kehidupan kekristenan, sebab agama-agama lain melandaskan keberadaan mereka sebagai agama ada ajaran-ajaran pendiri mereka; kekristenna berbeda dari semuanya itu karena keristenan melandaskan keberadaannya pada kematian Kristus. Kisah kehidupan Kristus disebut Injil: Semua peryataan Allah kepada makhluk-makhluk ciptaan Allah disebut Injil; dan secara lebih sempit istilah ini dipakai untuk kabar baik keselamatan. Apabil ameniadakan kematian Kristus sebagaimana yang ditafsirkan, berarti merendahkan kekristenan ke tingkat agamaagama etnis. Sekalipun memiliki system etika yang lebih tinggi, tanpa kematian Kristus di dalam kekristenan juga tidak ada keselamatan sebagaimana halnya agama-agama yang lain. Kematian Kristus penting untuk keselamatan, Allah tidak mungkin mengampuni dosa hanya berdasarkan pertobatan manusia, tindakan semacam itu tidak dapat mungkin dilakukan Allah yang benar. Allah hanya dapat mengampuni kalau hukumannya telah dijalani. Agar Tuhan dapat mengampuni manusia yang berdosa dan pada saat yang sama tetap benar, maka Kristus menjalani hukuman orang berdosa." 30

\footnotetext{
${ }^{30}$ Henry C Thiessen, Teologi Sistimatika, ed. Vernon D Doerksen, 8th ed. (Malang: Gandum Mas, 2010).
} 


\section{Implementasi Kematian Kristus dalam Kehidupan Kristiani}

Hidup yang bertumbuh dan berbuah

Untuk menjadi pribadi yang benar-benar mengalami perubahan dalam hidup karena menghayati, mehamai, dan meresponi kematian Kristus. Maka akan ditandai dengan kehidupan yang selalu diperbaharui oleh kekuatan dan keterlibatan Allah dalam hidunya, yaitu keterlibatan Roh Kudus dalam mengatur dan menuntun kehidupan setiap orang. Ryrie menyatakan bahwa "Ketika Roh menguasai kehidupan seseorang, maka buah-buahnya akan menghasilkan dalam hidupnya." 31 Maksud dari pernyataan ini adalah untuk mengarahkan pada pemahaman tentang perubahan-perubahan yang akan terjadi sesorang untuk menjadi sama seperti Kristus.

Kehidupan seseorang yang telah meresponi kematian Kristus dan dipenuhi Roh Kudus, maka akan berdampak pada beberapa kualitas moral, yang disebut buah Roh, yaitu: Kasih. Artinya suatu sikap menggerakkan seseorang menempatkan Allah dan orang lain lebih utama dari dirinya sendiri, yaitu suatu semangat yang mendorong orang untuk memberi dan melayani. Kemudian Sukacita. Artinya suatu semangat kegembiraan yang bgerakar dalam iman, yang diekspresikan melaui nyanyian dan disertai semnagat yang optimis. Damai sejahtera. Artinya suatu ketenangan dalam diri yang berasal dari Allah dan berdasar pada kenyataan pendamaian dengan Allah melalui pengorbanan Kristus. Buah berikutnya yaitu Kesabaran. Artinya ditengah situasi yang sulit dan dalam hubungan dengan orangorang yang sulit. Begitu juga dengan kemurahan, Artinya mempraktekan hokum kasih dalam memperlakukan orang lain seperti yang diharapkan akan diperbuat oleh mereka. Selain itu kebaikan, kesetiaan, kelemah-lembuatans serta pengendalian diri. Artinya ada kualitas yang memberi pengendalian atas keinginan, khususnya keinginan-keinginan yang berhubungan dengan kedagingan. ${ }^{32}$

Kualitas moral yang dikonsepsikan oleh De Haan dipertegas oleh Ryrie bahwa "Kasih bukan hanya terdiri dari kelemah-lembutan, namun juga kekerasan atau yang disebut disiplin." 33 Sebagai orang percaya, perlu memahami bahwa kematian Kristus merupakandoktrin pokok dalam kekristenan. Karena itu setiap pribadi harus percaya bahwa Kristus benar-benar telah bangkit dari antara orang mati (bdk., Mat. 28:1-7; Kis. 1:3). Dan

\footnotetext{
${ }^{31}$ Charles C Ryrie, “Teologi Dasar Jilid II,” Yogyakarta: Yayasan Andi (1992): 164.

${ }^{32}$ Martin E. De Haan, Sari Mutiara Iman (Yogyakarta: Yayasan Gloria, 1997), 20.

${ }^{33}$ Martin E. De Haan, Sari Mutiara Iman.
} 
seharusnya hal ini lebih memotivasi atau mendorong kehidupan setiap orang untuk menjadi lebih baik dihadapan Tuhan. Menjadi orang Kristen haruslah bertumbuh dalam kehidupan rohaninya. Jika setiap orang mencermati keadaan dunia ini, maka masih banyak dijumpai orang-orang ber-KTP Kristen tapi hidupnya tidak mencerminkan kehidupan sebagai pengikut Kristus. Bahkan banyak orang yang masih hidup dalam kesenangan dunia ini, artinya hidup di luar Tuhan. Oleh kematian dan kebangkitan Kristus orang pecaya dilahirkan kembali kepada suatu hidup yang penuh pengharapan untuk menerima suatu bagian yang tidak dapat biansa, yang tidak dapat cemar, yang tidak dapat layu yang tersimpan di Sorga (1 Pet. 1:34). Ayat ini memberikan pengharapan bagi orang percya untuk hidup menyenangkan hati Tuhan.

\section{Dalam Pemberitaan Injil}

Dalam sepanjang sejarah manusia tidak ada mujizat yang lebih banyak disertai bukti yang nyata selain dari pada kematian Kristus. Kematian Kristus terbukti merupakan hal yang pasti dalam sejarah, dan patut dipercayai oleh semua orang. Para rasul adalah saksi mata kematian dan kebangkitan Kristus. Artinya ajaran para Rasul tidak didasarkan pada kesaksian orang lain, tetapi pengalam pribadi mereka yang dikonfirmasi oleh rasul-rasul yang lain sebaga saksi mata. Rasul-rasul memberitakan kebangkitan Kristus dengan mempertaruhkan nyawa mereka. Murid-murid yang kurang percaya ketika melihat Kristus bangkit berubah menjadi pewarta Injil (kebangkitan Kristus) yang tidak kenal lelah.

Gereja Kristen juga merupakan akibat yang ditimbulkan oleh peristiwa kematian, dan kebangkitan Kristus. Kuasa kematian dan kebangkitan Kristus seharusnya menjadi motivasi sebagaimana para Rasul berani memberitakan Injil. Melaksanakan Amanat Agung dalam wujud penanaman gereja atau memberitakan Injil harus dilaksanakan. Karena pemberitaan Injil merupakan salah satu ekspansi untuk mendongkrak pertambahan jumlah pengikut Kristus. ${ }^{34}$ Bahkan Rasul Paulus adalah salah satu murid Yesus Kristus yang berperan signifikan dalam penyebaran ajaran kekristenan pada abad mula-mula. Ini dilihat dari apa yang ia perbuat sebagai pemberita Injil dan perintis gereja-gereja lokal dalam pendirian

\footnotetext{
${ }^{34}$ Simon Simon and Semuel Ruddy Angkouw, "Perintisan Gereja Sebagai Bagian Dari Implementasi Amanat Agung," Manna Rafflesia 7, no. 2 (2021): 210-234.
} 
gereja baru melalui misi penginjilannya, serta ia juga merupakan rasul yang produktif dalam menulis surat-surat kepada gereja yang ia rintis. ${ }^{35}$

\section{Kesimpulan}

Untuk membuktikan kebenaran kematian Kristus yang sesuai dengan pernyataan Alkitab, maka telah dilakukan pengkajian terhadap kematian Kristus secara dogmatik. Berdasarkan paparan di atas terbukti Kristus benar-benar mati sebagai manusia yang sejati untuk menebus dosa seluruh umat manusia. Semua fakta ini mendukung pandangan alkitabiah serta menguatkan keyakinan bahwa sesungguhnya Kristus Yesus yang adalah Allah-Manusia, telah mati sebagai korban suci untuk keselamatan umat manusia. Alkitab secara tegas menyatakan bahwa Kristus mati dan itulah yang saat ini dipercayai oleh orang Kristen di masa kini. Dari urain ini menunjukkan bahwa Alkitab baik PL maupun PB menjelaskan bahwa Kristus benar-benar mati untuk manusia. Dan kebenaran ini telah dinyatakan Allah sejak kekekalan. Kristus harus menebus manusia yang berdosa sehingga manusia kembali berharga di hadapan Allah yang maha kudus. Kristus mati dengan penderitaan, yang tidak manusiawi sebagaimana tujuan pelaksanaan hukuman penyaliban yang adalah hukuman untuk mempermalukan terhukum serta membuat penderitaan menjadi sangat lama dengan mati perlahan-lahan.

\section{Referensi}

Barbara, Thiering. "Jesus and the Riddle of the Dead Sea Scrolls." San Francisco (1992).

Chris Marantika. Kristologi. Jakarta: Iman Press, 2005.

Douglas, J D, and others. "Ensiklopedi Alkitab Masa Kini Jilid I.” Jakarta: Yayasan Komunikasi Bina Kasih/OMF (2003).

Geisler, Norman L. Ketika Alkitab Dipertanyakan. ANDI, 2006.

Hartopo, Yohanes Adrie. "Kematian Yesus Kristus Menurut Lukas 23: 44-48.” Jurnal Amanat Agung 13, no. 2 (2017): 207-241.

Henry C. Thiessen. Teologi Sistematika. Cetakan Ke. Malang: Penerbit Gandum Mas Malang, 2010.

Henry C Thiessen. Teologi Sistimatika. Edited by Vernon D Doerksen. 8th ed. Malang:

\footnotetext{
${ }^{35}$ Simon Simon, "Peran Roh Kudus Bagi Hamba Tuhan Dalam Merintis Gereja," LOGIA: Jurnal Teologi Pentakosta 1, no. 2 (2020): 41-64.
} 
Gandum Mas, 2010.

Karim, Abdul. "Sejarah Perkembangan Ilmu Pengetahuan.” Fikrah 2, no. 2 (2014).

Linnemann, Eta. Teologi Kontemporer: Ilmu Atau Praduga? Istitut Injil Indonesia, 1991.

Maman Abdurahman, Sambas Ali Muhidin, Ating Somantri. Dasar-Dasar Metode Statistika

Untuk Penelitian. Bandung: CV Pustaka Setia, 2011.

Marinella, Mark A. Yesus Yang Disalib Bagiku. Yogyakarta: ANDI, 2009.

Martin E. De Haan. Sari Mutiara Iman. Yogyakarta: Yayasan Gloria, 1997.

Oet, Supriadi. "Teladan Penderitaan Tuhan Yesus Berdasarkan Matius 27: 32-44.” Manna Rafflesia (2020).

Paul Enns. The Moody Hanbook Of Theology. Malang: SAAT, 2010.

Purwoto, Paulus. "Tinjauan Teologis Tentang Gereja Sejati Dan Aplikasinya Bagi Pelayanan Gereja Kontemporer." SHAMAYIM: Jurnal Teologi dan Pendidikan Kristiani 1, no. 1 (2020): 45-57.

Putrawan, Bobby Kurnia, Edi Sugianto, and Yan Kristianus Kadang. "Refleksi Pada Relasi Antara Teologi Dan Filsafat Dalam Perspektif Teologi Injili." Evangelikal: Jurnal Teologi Injili dan Pembinaan Warga Jemaat 4, no. 2 (2020): 223-234.

Russell, Bertrand, and James J Ravell. Why I Am Not a Christian. Haldeman-Julius Publications, 1929.

Ryrie, Charles C. “Teologi Dasar Jilid II.” Yogyakarta: Yayasan Andi (1992).

Ryrie, Charles C, and Teologi Dasar. “Cet 3.” Yogyakarta: Yayasan Andi (1986).

Simon, Simon. "Peran Roh Kudus Bagi Hamba Tuhan Dalam Merintis Gereja." LOGIA: Jurnal Teologi Pentakosta 1, no. 2 (2020): 41-64.

Simon, Simon, and Semuel Ruddy Angkouw. "Perintisan Gereja Sebagai Bagian Dari Implementasi Amanat Agung." Manna Rafflesia 7, no. 2 (2021): 210-234.

Walvoord, John F. “Yesus Kristus Tuhan Kita.” Surabaya: Yakin (1969).

Zaluchu, Sonny. "Penderitaan Kristus Sebagai Wujud Solidaritas Allah Kepada Manusia." DUNAMIS: Jurnal Penelitian Teologi dan Pendidikan Kristiani (2017).

Zaluchu, Sonny Eli. "Metode Penelitian Di Dalam Manuskrip Jurnal Ilmiah Keagamaan.” Jurnal Teologi Berita Hidup 3, no. 2 (2021): 249-266. 